
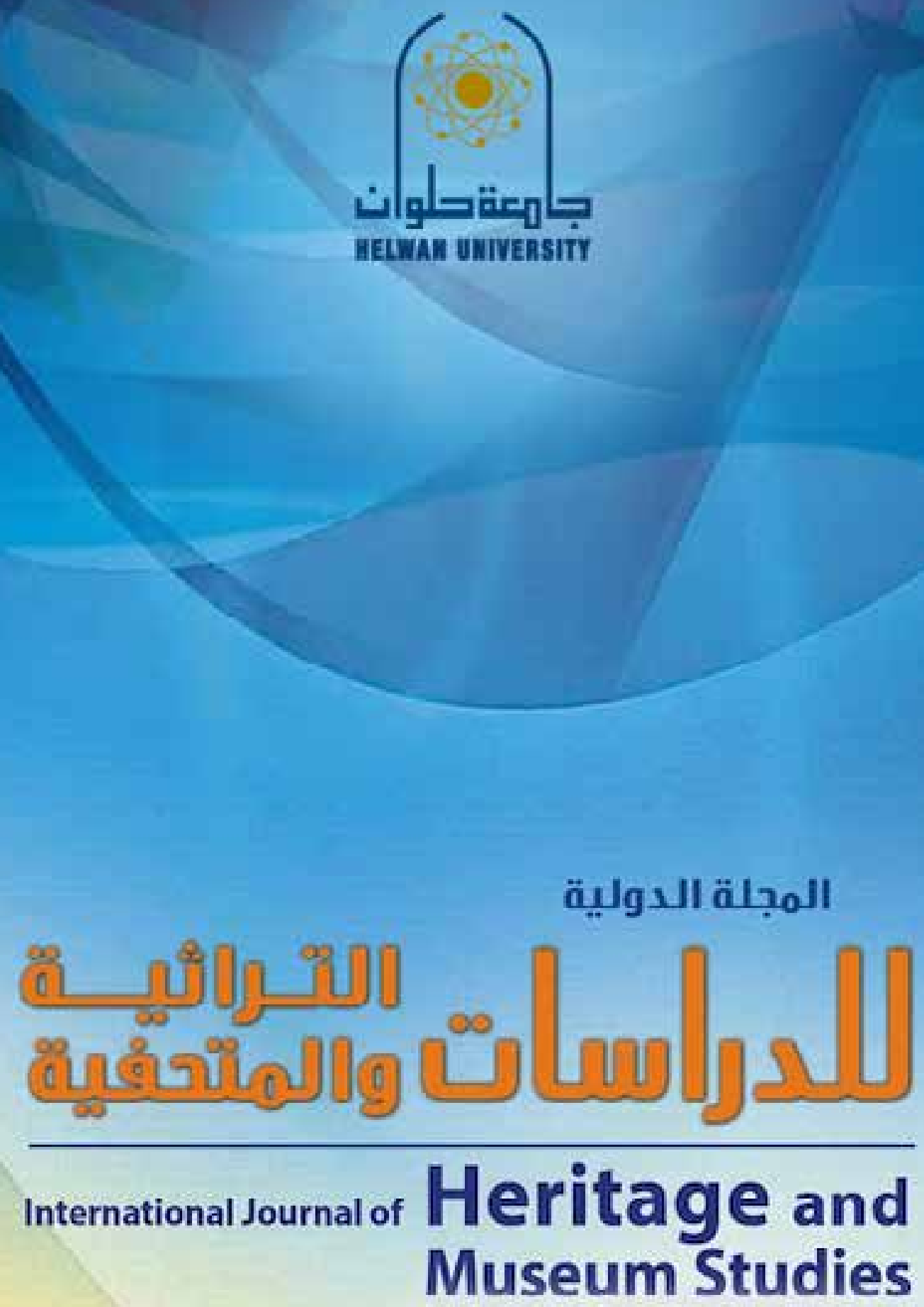

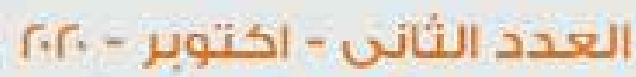
Volume 2 - October - 2020

https://jhms.journals.ekb.eg 


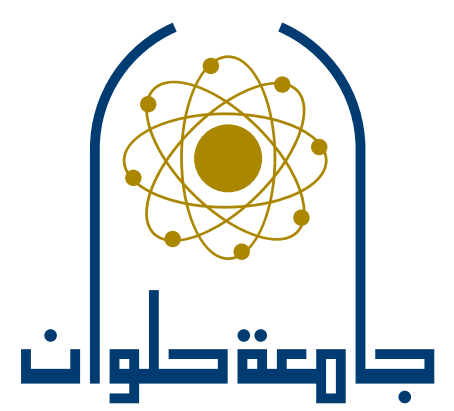

HELWAN UNIVERSITY

\section{International Journal of Heritage and \\ Museum Studies}

\section{IJHMS}

المجلة الدولية للدراسات التراثية والمتحفية

Volume 2-2020

Edited and Published by:

Faculty of Tourism and Hotel Management - Helwan University 
The INTERNATIONAL JOURNAL OF HERITAGE AND MUSEUM STUDIES (IJHMS), established in 2017, is an academic peer-reviewed multidisciplinary journal published annually in print and online in English language. It Studies, Popular History, Conservation and Restoration Techniques, Interpretation and Design.

\section{IJHMS Editorial Board}

Prof. Hosam Refai

Prof. Doaa Kandil

Assoc. Prof. Mary Misak

Prof. Heba Abd El Aziz

Prof. Nikolaos Lianos

$\begin{array}{lll}\text { Prof. Leo Schmidt } & \text { Brandenburg University of Technology, Cotbus, Germany } \\ \text { Prof Michael Schmidt } & \text { Brandenburg University ofTechnology, Cotthus, Germany }\end{array}$

Editor-in-Chief (Helwan University)

First Editor (Helwan University)

Second Editor (Helwan University)

German University of Technology, Oman

Democritus University of Thrace, Xanthi, Greece

Prof. Antonio Medina-Rivera Cleveland State University, USA

\section{IJHMS Board}

Prof. Soha Abdel Wahab Dean, Faculty of Tourism \& Hotel Management

Prof. Hosam Refai

Prof. Aly Abdallah

Prof. Rehab Assem

Prof. Rasha Metawi

Prof. Hazem Attiatalla

Prof. Heba Youssef

Prof. Nagwa Arafa

Prof. Doaa Kandil

Assoc. Prof. Mary Misak

Mrs. Sabah Muhammad

Conth-int

Coordinator, Bachelor Program of Heritage and Museum Studies

Coordinator, PhD Program of Heritage and Museum Studies

Professor, Department of Tourism Guidance

Professor, Department of Tourism Guidance

Professor, Department of Tourism Guidance

Professor, Department of Tourism Guidance - First Editor (Helwan University)

Journal Secretary
ميئة التحرير

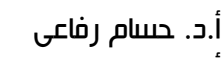

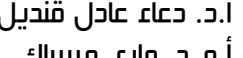

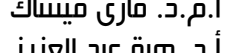

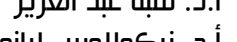

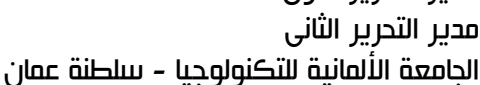

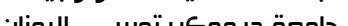

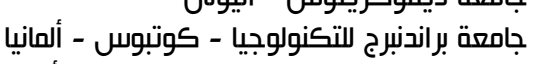

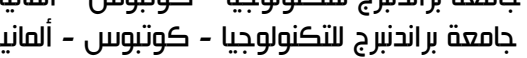
جامعة كليفلاند ستيت - الولايات المتحدة الأمريكية

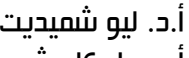

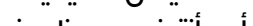

مجلس الإدارة

عميد كلية السياحة والفنادق

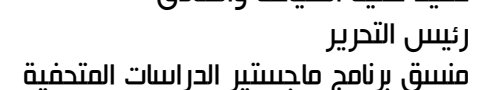
منسق برنامج بكالوريوسل الدراسات التراثية والمتحفية منسق برنامج دكتوراه الدراسات التراثية والمتحفية

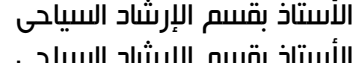

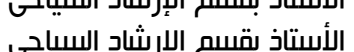

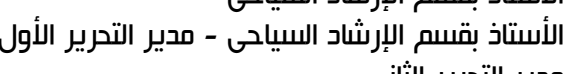

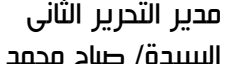

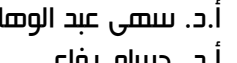

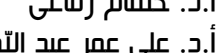

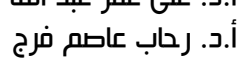

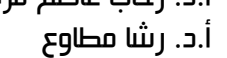

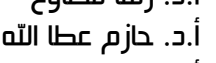

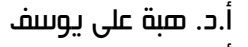

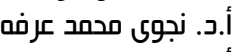

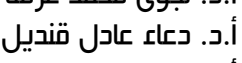

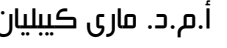
سكرتارية إدارية
Manuscripts to be sent to: ijhms@fth.helwan.edu.eo Journal Website: https://ijhms.journals.ekb.e

Post: IJHMS, Faculty of Tourism and Hotel Management, Helwan University, 1 Abdel Aziz Al-Soud. Str., Manial, Cairo, Orma Post 12612

Fax: +202 23652795

(CHelwan University, Cairo, Egypt.

The editorial board of IJHMS would like to express their deepest gratitude for the esteemed reviewers, listed alphabetically below, who reviewed the papers of the second volume and willingly shared with us their valuable insight and expertise

\begin{tabular}{|l|l|}
\hline \multicolumn{2}{|c|}{ Reviewers of Volume 2} \\
\hline Prof. Soha Abdel Wahab & Helwan University \\
\hline Prof. Ahmed Al Shoky & Ain Shams University \\
\hline Prof. Nagwa Arafa & Helwan University \\
\hline Prof. Rehab Assem & Helwan University \\
\hline Prof. Hazem AttiatAllah & Helwan University \\
\hline Prof. Engy El Kilany & Minia University \\
\hline Prof. Nashwa El Sherif & Helwan University \\
\hline Prof. Doaa Kandil & Helwan University \\
\hline Prof. Rasha Metawi & Helwan University \\
\hline Prof. Nahla Nassar & Helwan University \\
\hline Prof. Hosam Refai & Helwan University \\
\hline Prof. Dalia Soliman & Helwan University \\
\hline Prof. Tarek Tawfik & Cairo University \\
\hline Prof. Rasha Soliman & Misr University for Science \& Technology \\
\hline
\end{tabular}

Special thanks are due to the language reviewer of IJHMS

Dr. Mona Saad - Helwan University

Designer \& Art Director of IJHMS

Dr. Ramy Kenawy - Helwan University 


\section{Contents}

\section{Esraa Alhadad, Maissa Moustafa, Mariam Dawoud and} Nesma Ahmed

Elephantine Island: The Neglected Site A Case Study

from Visitor Management Approach.

\section{Rania Ali Maher and Noha Moustafa Shalaby}

Tracing the History of Museums in Egypt

from the Ptolemaic Period to the Fall of Mohamed Ali's Dynasty

(323 BC - AD 1952)s

\section{Mona M.Raafat El-Sayed and Randa Alaa El-Din Fouad}

An Insight into an Egyptian Intangible Cultural Heritage Tradition:

The Hammām

\section{Randa Alaa El-Din Fouad}

National and International Approaches to Combat

Cultural Heritage Trafficking in Post-2011 Egypt.

\section{Shreen Mohamed Amin, Hosam Refai and Rasha Kamal}

Mapping Industrial Heritage Sites in Egypt: Identification \& Management
Shreen Mohamed Amin, Hosam Refai and Rasha Kamal

Adopting Conservation Polices for Industrial Heritage Museums:

A Case Study of the Railways Museum, Cairo Egypt

Rania Mostafa Eshaq Abdalla, Ali Omar Abdallah and Osama Abd El-Wareth Abd El-Megiud

The Impact of Using Digital Technology Applications on the Egyptian Museum's Display

Rania Mostafa Eshaq Abdalla, Ali Omar Abdallah and Osama Abd El-Wareth Abd El-Megiud

The Egyptian Museum in Cairo (EMC) Past and Present .....

Elham Salah Eldin Mohamed Aly, Aly Omar Abdallah and Guido Fackler

The Role of the Museums in Lifelong Learning for Adults

Elham Salah Eldin Mohamed Aly, Aly Omar Abdallah and Guido Fackler

The Role of Sohag National Museum in Reflecting Egyptian

Tangible and Intangible Heritage

Shaimaa Nagib, Ghada Hammoud, Hosam Refai and Manal Bourhan

Baron Palace Myths: A Horror Tourism Destination in Egypt 


\title{
Elephantine Island: The Neglected Site A Case Study from Visitor Management Approach
}

Esraa Alhadad, Maissa Moustafa, Mariam Dawoud and Nesma Ahmed

\begin{abstract}
Elephantine Island at Aswan Governorate is one of the unique archaeological sites in Egypt representing a historical timeline of Egypt starting from 3000 BC. Moreover, its location adjacent to two Nubian villages - Kotti and Sew - with their inhabitants makes the island a distinctive cultural site where tangible and intangible heritage are mixed together.

Nevertheless, the site suffers from negligence and poor interpretation, which on the one hand made the domestic and international tourists unaware of the major significance of the site. On the other hand, the local community is deprived of any kind of development.

In this paper, the authors aim to spot the main issues and opportunities of the heritage site on Elephantine Island. As a result of the research, the authors recommend four different approaches in order to develop the site from a visitor management approach: accessing the site, interpretation, community involvement and marketing.

The methods used in the analysis are mainly reviewing literature, making interviews and using the latest technology (GIS web mapping and $3 \mathrm{D}$ reconstruction).
\end{abstract}

\section{Keywords}

Elephantine Island, Aswan, Heritage Conservation, Heritage Site Management, Community Involvement, Visitor Management, Heritage Marketing

\section{Introduction}

Elephantine Island at Aswan Governorate is one of the unique archaeological sites in Egypt representing a historical timeline of Egypt starting from 3500 BC. Nevertheless, the site suffers from negligence and poor interpretation, which made domestic and international tourists unaware of its major significance.

In this case study, the authors are trying to spot the main issues and opportunities of the archaeological zone on Elephantine Island. The first part of the research is dedicated to determining the significance of Elephantine in relation to its location at the south of Egypt. In the second part the authors are concerned with analyzing the current situation of Elephantine by approaching the island from different perspectives, amongst all tourism and local community. The third part includes recommendations of the authors on how to better understand and protect the site in order to create a sustainable tourism through four different approaches, namely accessing the site, interpretation, community involvement and marketing. The fourth section is dedicated to the conclusion of the research.

The methods used in the analysis are mainly reviewing literature, interviews made with visitors and the local community, not only in Elephantine Island but also in other sites as Dahshur Necropolis, and interviews with technical specialists. Moreover, the authors used the latest technology to make a 3D modeling videos and images for the ruined monuments, and the GIS web mapping by measuring the site's monuments coordinates to create a website. 


\section{The Significance of Elephantine}

Elephantine is the Nile Island located opposite the modern city of Aswan. This rocky, stretched island is the biggest in the island group of the first cataract. ${ }^{1}$ On a granite outcrop at its southeastern end, the island contains the ruins of the ancient town of Elephantine, which was the capital of the first Nome of Upper Egypt and home of the triad Satet, Khnum and Anuket of Sehel. ${ }^{2}$ This town dates back to the Middle Naqada Period 3500 BC and was inhabited until the early Arab Period, producing an archaeological tell. ${ }^{3}$

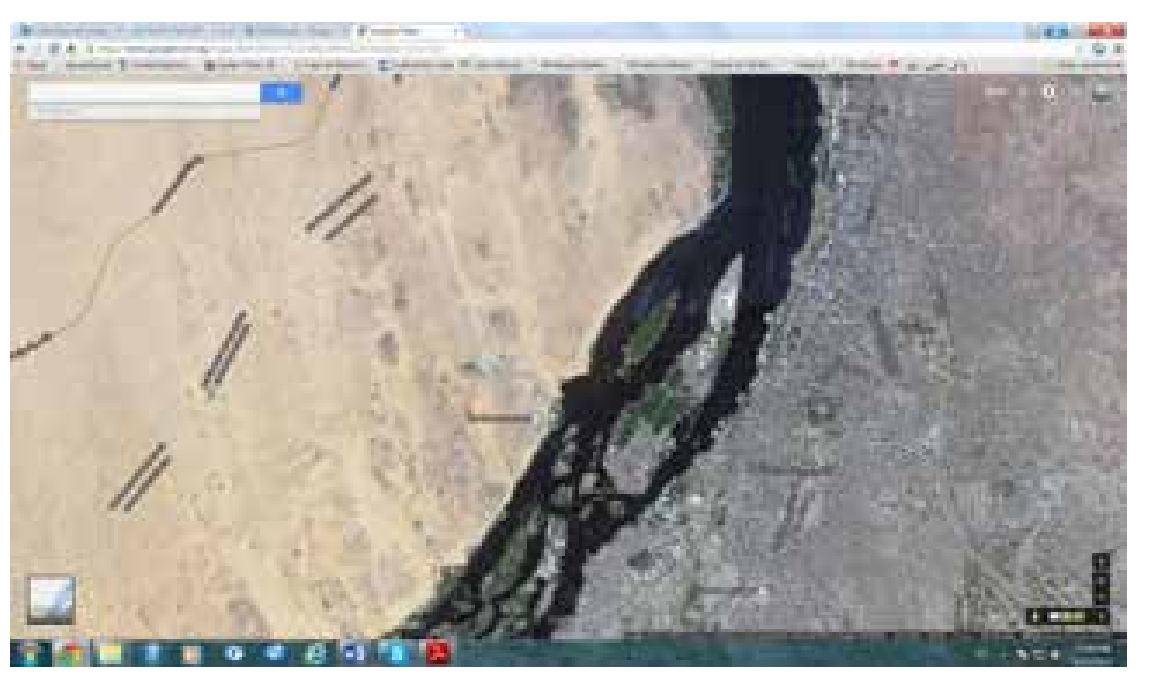

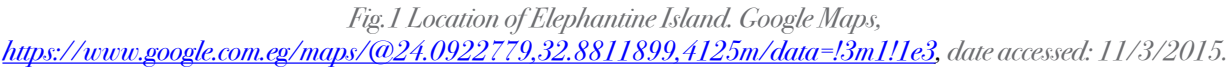

The name "Elephantine" was derived by the Greeks from the Ancient Egyptian name given to the island Abu, translated "elephant land", "elephant" or "elephant ivory". ${ }^{4}$ The elephant-shaped rocks surrounding the island or the trade of elephant ivory in former times at that location could be reason for this name. ${ }^{5}$ Nowadays Elephantine is locally called Geziret Aswan (Island of Aswan). ${ }^{6}$
On the west bank opposite the island the tombs of Qubbet el-Hawa, the tomb of the Agha Khan and the ruins of the Monastery of St. Simeon are located. ${ }^{7}$

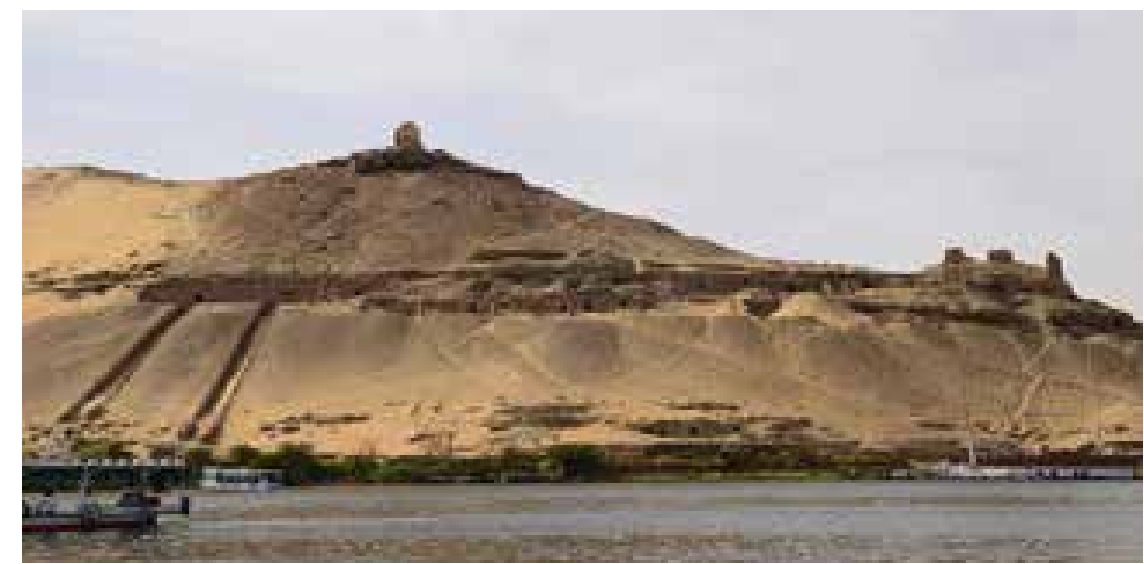

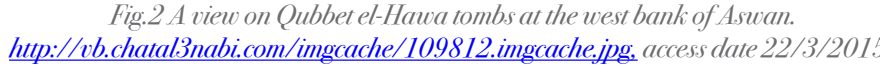

The first excavations at the archaeological site of Elephantine took place in 1906 by Rubensohn, continued by Clermont-Ganneau, Strazzulli, Ed. Ghazouli and Labib Habachy. ${ }^{8}$ Afterwards, the site has been systematically excavated and studied since 1969 by the German Archaeological Institute in cooperation with the Swiss Institute for Architectural and Archaeological Research on Ancient Egypt.'

The location of Elephantine Island gave it a strategic importance throughout history. First of all, Elephantine acted as an important commercial centre in Egypt. As the southernmost city within the Egyptian boundaries, Elephantine was the storing point for goods exported from southern countries ${ }^{10}$ and it was the trading centre for granite, minerals and semi-precious stones quarried at Elephantine and the surrounding area.

On Elephantine Island the first cult of goddess Satet was established during the Late Naqada Period. At that time, her sanctuary had a very primitive form, consisting of a simple mud brick structure between three granite rocks. The development of this sanctuary into a temple throughout time is a unique example that cannot be found anywhere else in Egypt. ${ }^{13}$

As part of the Egyptian territory, Elephantine played a role of expressing the centralized ruling power and authority of Egypt at that time by building a pyramid in the third dynasty and the continuous constructions at the temples an the town by different kings. ${ }^{14}$

\section{Elephantine, 41 .}

8 Habachi, Habachi, “Elephantine," 121

9 Elephantine, 5 .

10 Ikram

11 Habachi, “Elephantine,"1222; Habachi, “"Hekaib the Deified Governor," 10.

12 Elephantine, 9; Habachi, “Elephantine," 1222

13 Elephantine, 19.

14 Ibid, 10 . 
Another significant role of Elephantine was measuring the height of the annual inundation for taxation using the two Nilometers connected to the temples of Khnum and Satet.

The site of Elephantine provides a wide range of historical and archaeological information due to its complex layers of history, which could be viewed at the $12 \mathrm{~m}$ high profile of archaeological layers at the southern part of the site. ${ }^{16}$

Another significant aspect is the Heqaib's sanctuary, which represents an example of the cult of a private person established at a settlement. Heqaib was the governor of Elephantine during the reign of Pepi II. His sanctuary and cult were established after his death and they were of regional importance.

Elephantine was considered as a garrison town and a fortress against any attacks from the southern borders. ${ }^{18}$ It was also the starting point for the so called "Nubian Highway" to reach the second cataract."

In 1902 a colonial style building was erected at the eastern part of the site as a residential and administrative building for the directing engineer of the Aswan Dam at that time. Later in 1912 it was annexed to the Ministry of Education and then in 1917 it was converted into the current Aswan Museum as the first provincial museum of Egypt. In 1958 a storage room and two halls were added to the building by Labib Habachi.

Right to the north of it another smaller museum, the so-called Annex Museum was built in 1991/1992 to display the excavation works conducted since 1969 on the island. ${ }^{20}$

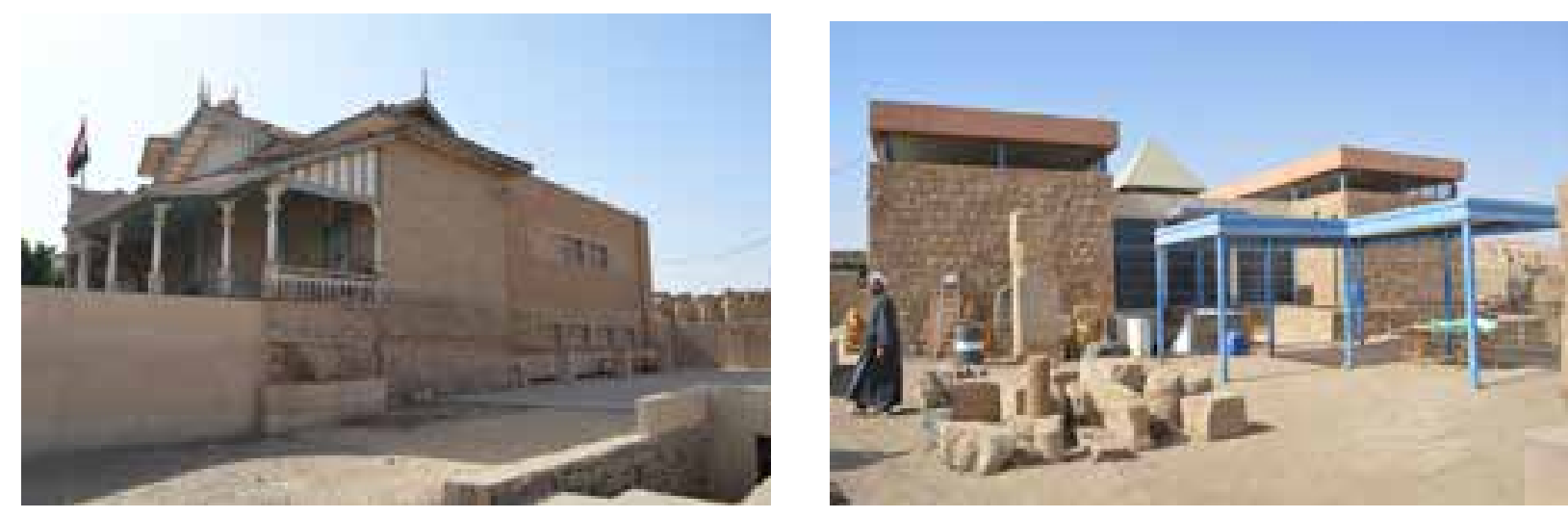

Fig.3 A.svan Museum (lefi). Anner Musseum (righti). ONesma Ahmed, 2015.

\section{Analysis of the current situation}

To be able to understand the real situation on Elephantine Island, three factors should be taken into consideration: A SWOT analysis for the historic site, an analysis from the tourism perspective and finally how the local community, who live nearby the archaeological tell, see and appreciate the importance of the site.

Ikram and Knobla

6 Elephantine, 3

19 -

20 Elephantine, 57; Melek, (actual director of Elephantine Museum), interview by author, March 102015.
The latter two approaches are considered as the two main issues related to the site and they are also of major importance according to researchers. Nowadays the heritage tourism is believed to be the driver of development in underdeveloped countrie ${ }^{21}$ and especilly in Egypt; tourism has been consided as one of the most important economdeverources. How reson in was inithed by he UN w intellectual being ${ }^{23}$.
21 Brooks, "Heritage," 496 .
22 "Clobal Code of Fthics,"

23 Brooks, "Heritage," 497 


\section{1-SWOT Analysis}

\begin{tabular}{|c|c|c|c|}
\hline Strengths & Weaknesses & Opportunities & Threats \\
\hline $\begin{array}{ll}\text { - } & \text { Limited area } \\
\text { with clear } \\
\text { boundaries } \\
\text { - } & \text { Uniqueness } \\
\text { - } & \text { Relevant histor- } \\
\text { ical value and } \\
\text { heritage signifi- } \\
\text { cance } \\
\text { - Aesthetic value }\end{array}$ & $\begin{array}{l}\text { Very poor inter- } \\
\text { pretation of the } \\
\text { site, mainly for } \\
\text { the reconstruct- } \\
\text { ed area } \\
\text { No visitor facil- } \\
\text { ities } \\
\text { Very fragile } \\
\text { site, most of it } \\
\text { closed area }\end{array}$ & \begin{tabular}{|l} 
High potential \\
for different \\
types of tourism \\
(historic site + \\
the village) \\
Different types \\
of creative fund- \\
ing
\end{tabular} & 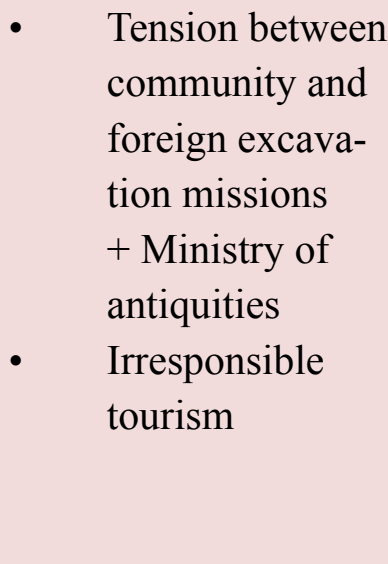 \\
\hline Strengths & Weaknesses & Opportunities & Threats \\
\hline $\begin{array}{ll}\text { - } & \text { Archaeological } \\
\text { value } \\
\text { - } & \text { high level of } \\
\text { - } & \text { authenticity } \\
\text { - } & \text { Accessibility } \\
\text { Scientific value }\end{array}$ & $\begin{array}{l}\text { Signage unseen } \\
\text { and of wrong } \\
\text { material } \\
\text { Lack of infor- } \\
\text { mation about } \\
\text { the transpor- } \\
\text { tation to the } \\
\text { island } \\
\text { Lack of funds } \\
\text { No marketing } \\
\text { plan }\end{array}$ & $\begin{array}{ll}\text { - } & \text { Untraditional } \\
\text { site to visit } \\
\text { Part of master- } \\
\text { plan for visiting } \\
\text { Aswan made by } \\
\text { DAI }\end{array}$ & $\begin{array}{l}\text { - Lack of aware- } \\
\text { ness by the } \\
\text { community } \\
\text { Negligence of } \\
\text { a management } \\
\text { plan for the site. } \\
\text { Political insta- } \\
\text { bility }\end{array}$ \\
\hline
\end{tabular}

\section{Touristic approach}

In order to include the site of Elephantine Island in the visitation on the touristic map, it is important to compare the visitors' numbers in other two directly competing sites in Aswan, such as the unfinished obelisk as an archeological site, and the Botanical Garden as an island. ${ }^{24}$

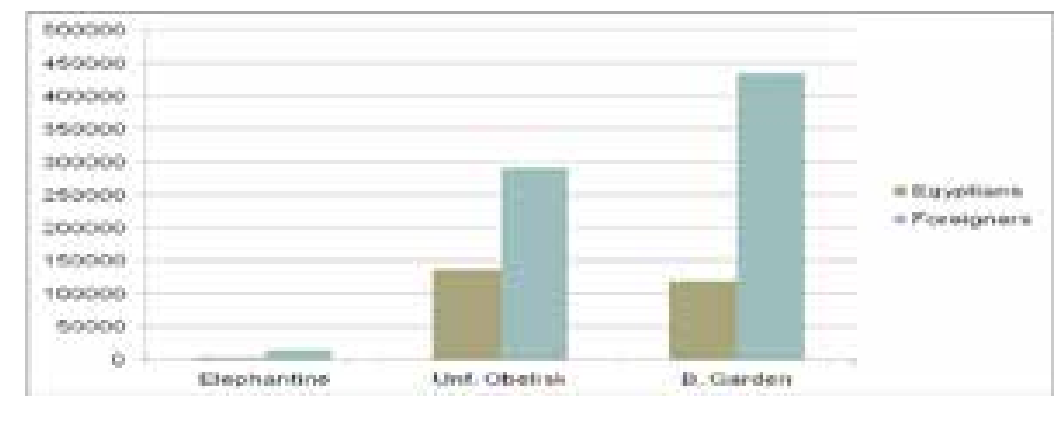

Fig. 4 Comparison showing the number of visitors at the three sites in 2009.

Egyptians

\section{Foreigners}

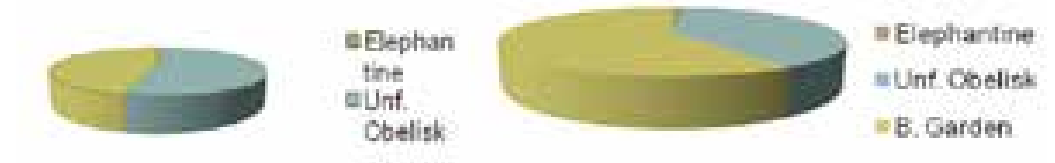

Fig.5 The share of Elephantine Island of Egyptian and foreign visitors compared to both competing sites.

\section{From the comparison one could conclude the following facts:}

1. The number of Egyptian visitors is incomparable to the number of foreign visitors at the Unfinished Obelisk and the ratio is the third at the Botanical Garden.

2. Elephantine Island doesn't almost exist on the tourism map compared to the other two sites. It is obvious that the site has been neglected from the Ministries of Antiquities and Tourism, tour operators, travel agencies and individuals. Consequently, the site badly needs a good management and marketing plan to attract both Egyptian and foreign visitors.

\section{Relation between the local community (modern villages) and the historic site}

\section{A. The status of the actual modern village}

The inhabited part of the Island is divided into two modern parts or $\mathrm{Naga}$ ' separated by an agricultural land: the upper Kotti, and the lower, Sew. After the construction of the High Dam during the 60s the number of dwellers has increased because the island wasn't flooded by the Nile water anymore and therefore had a solid soil for building houses 
Nowadays the number of inhabitants is between 3500 and 5000 inhabitants, where half of them is working as sailors on Feluccas and motorboats for tourists. The other half are working in the tourism sector as transfers and guides. There are two mixed schools on the island: a primary school and a secondary one with 20 maximum pupils in each class.

It is worth mentioning that the state of infrastructure and services on the island is suffering from severe problems, such as collecting the garbage, the mosque's maintenance and the transportation to and from Aswan city. They are mainly conducted by he con Aswan Island. The

\section{B. The site and the tourism from the point of view of the community}

During the first half of the 20th century, the archeological site on Elephantine was considered as a nasty place because of the presence of crosses and sculptures - the remains of "paganism " - on some ruins. The few foreign tourists who visited the archeological site were seen as kafry (disbelievers) and they were unwelcome by the people. Due to the long history of colonialism, these visitors were considered as strangers from other worlds and scabies because of their different color skin.

With the beginning of the mass tourism in the second half of the 80 s, this perspective has been changing because of the better education, the general awareness and the direct benefit from tourism. However, there are certain impacts of tourism on the lifestyle of the community. On the one hand there were negative impacts, like:

- Marriage of young people with old foreign ladies

- The decreasing value of education against the increasing value of gaining money

- The loss of many genuine traditions of the Nubian culture

On the other hand, there were positive impacts. The social and the economic level of some individuals increased through cross cultural interaction with foreign visitors and marriage with foreign young women.

As for the different types of tourism that could be carried out on the island, three types are suggested:

1. Cultural tourism in the historic archeological part

2. Socio-ethnic tourism in the modern village

3. Eco-tourism, e.g., bird watching and information on botanical features in Lower Nubia

One of the successful touristic private projects on the island is the Animalia Museum, established by one of the intel-

25 Abbas Hegayy, interview by author, February 132015

Eng. Abbas Hegazy (60) years is the cousin of the famous Nubian singer Mohamed Hamam and the nephew of the last mayor of elephantine in 1957. lectuals from the local community. Animalia is a private bio-ethnic museum about Nubia and the owner offers three types of guided tours:

1. Tour through the museum

2. Walking tour through the village

3. Tour in the archaeological zone $e^{2}$

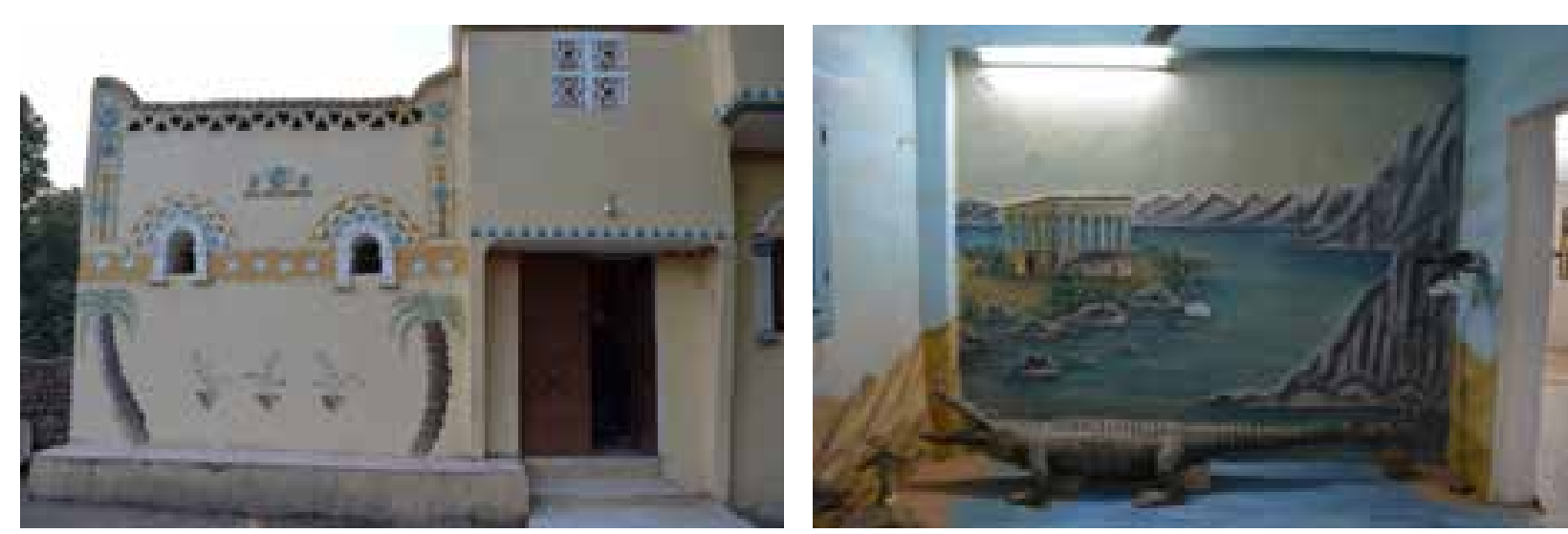

Iig. 6 Animalia Museum. ONesma Ahmed, 2015.

\section{Recommendations}

In order to develop Elephantine site as an important heritage site that has been unfortunately neglected for many decades, the researchers suggest the following four different approaches:

1. Accessing the Site

Site Interpretation

Community Involvement

Marketing Campaign

\section{Accessing the site}

The best way to access the site from the Nile is to establish a private marina for the site, on the east bank of Aswan city, provided with a big banner showing "Elephantine Island". Beside this marina, a kiosk to sell the tickets of the site could be established. Scheduled ferry boats are to be announced. 


\section{Site interpretation}

\section{PresentingInformation on the Site}

After many interviews with local and foreign visitors, ${ }^{27}$ the most desirable request is to have clear direction arrows and a simple site map, given with the ticket at the entrance from the ticket office, provided with the name of the attractions. Once they reach the monuments, the sign will explain the main features of each in a simple way.

As nearly everyone is using a smart phone, using QR code in front of the monument, which is linked to a website, is a good tool. As an example for this point, the website http://cultmap.cultnat.org/abu had been created for this case study. It is a web mapping solution providing information about the archaeological zone of Elephantine Island at its
southern part using GIS technology ${ }^{28}$ Another possibility is developing a mobile application about the island, where the visitor can get the information by entering the monument's name or number.

The researchers suggest some English and Arabic translations of the important Hieroglyph sentences engraved on the main blocks, e.g., the block that carries the title of god Khnum nb kbhw hry ib abw, which means "Lord of the cold werk

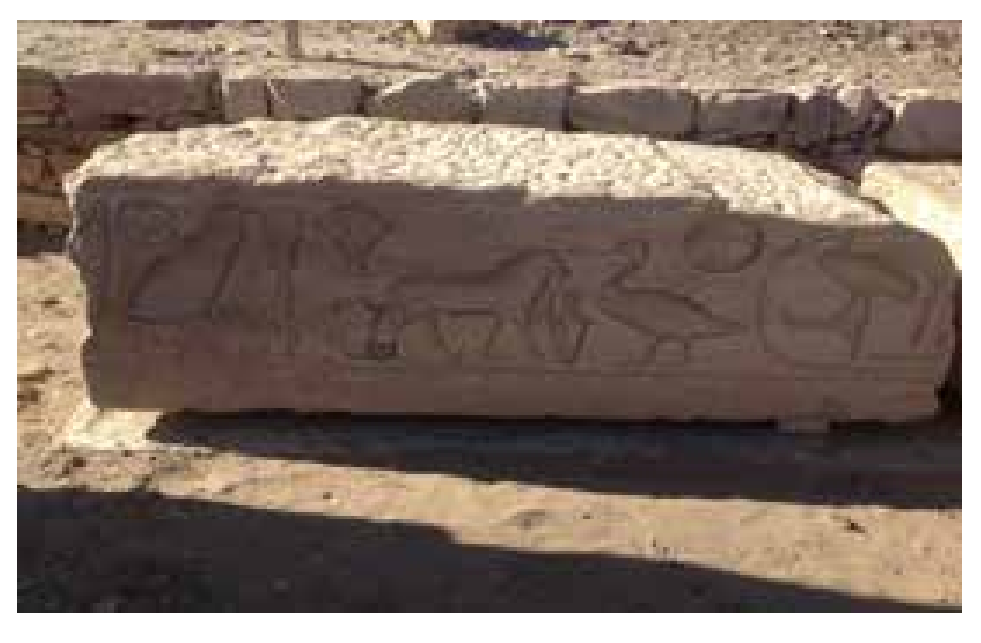

Fig.7 Blocks of Khnum Temple. ONesma Ahmed, 2015
As the site of Elephantine is suffering from limited space for reconstructions and the majority of the monuments is ruined and missing its original material, virtual aids, such as virtual reconstruction and Augmented Reality (AR), would be the best solution to restore monuments in a meaningful way so that visitors can understand them. An example would be using AR in showing the inscriptions and wall paintings of Satet Temple.

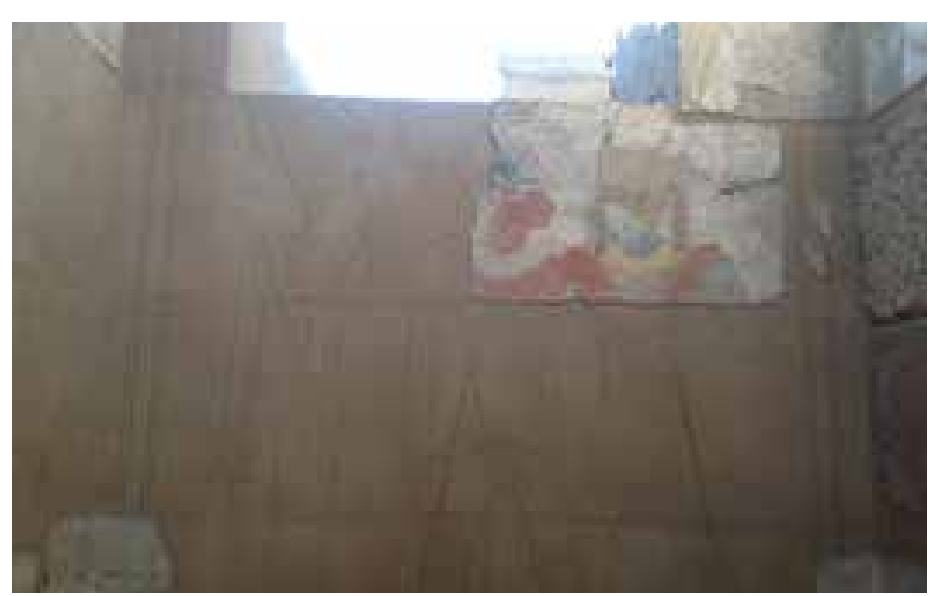

Fig.8.8 Inscriptions and paintings of Sater Temple. ONesma Ahmed, 2015.

\section{A. On-site Museums}

\section{(1) Elephantine Museum}

The researchers suggest that this museum, which is considered as the only colonial building remaining visible in Aswan, as well as the first provincial museum in Egypt in 191729, should be kept as a provincial museum. The following theme and scenario should be developed for the museum:

Many rooms have to remain as a provincial museum, mainly for the finds of the site such as those of Heqaib. However, another room, mainly at the entrance of the museum at the center, could be transformed to an information office to provide visitors with maps, different tours, brochures, and local guides.

Other rooms could serve as ICT center with a screen to display a film ${ }^{30}$ of virtual reconstructions for the land and other interactive screens to get information and fun (as an example, a virtual reconstruction of the site had been made for the case study). The visit of these rooms is suggested to be done at the end of the tour.

3. A Virtual reconstruction of the procession of Satet Temple throughout history could be displayed in one of the museum's rooms, as well as a virtual reconstruction of one of the houses of the Middle Kingdom and Khnum Temple ${ }^{31}$ in the ICT room of the museum with an indication, on the map and on the sign, of the presence of this technology inside the Museum. 

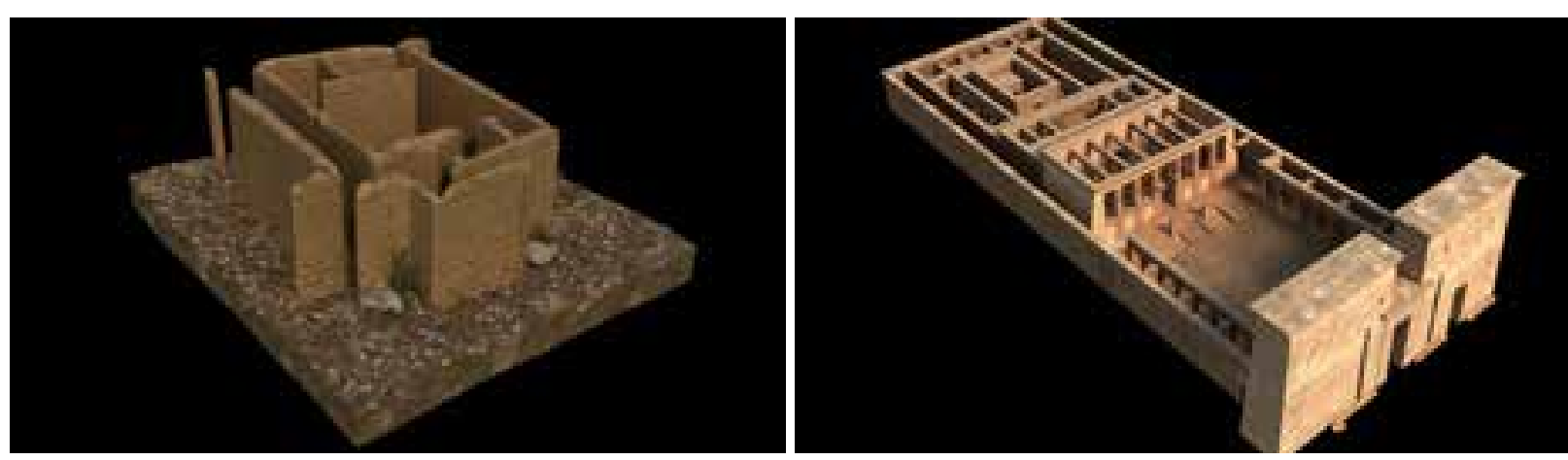

Fig. 9 Virtual reconstruccion of a Middle Kingdom house (left) and of Khnum Temple (right). Affer: Eng. A. ALY, CULNAT, using house plans published by

4. The garden of the museum could be transformed to a pleasant cafeteria which presents some local refreshments and beverage to visitors, such as Carcadé (hibiscus), Tamaris or Doom. This will be appreciated by visitors; ments and beverage to visitors, such as Carcadé (hibiscus), Tamaris or Doom. This will be appreci.
especially after a tiring visit on the site under the sun (a free drink might be included in the ticket).

(2) Annex Museum

At this museum information on excavations and reconstruction process could be offered to visitors at the end of their tour. One room might be for the reconstruction process provided with photos showing the work from 1969 to 1973. Another room with a screen showing a documentary film about the excavations and show cases of some excavation materials and equipment.

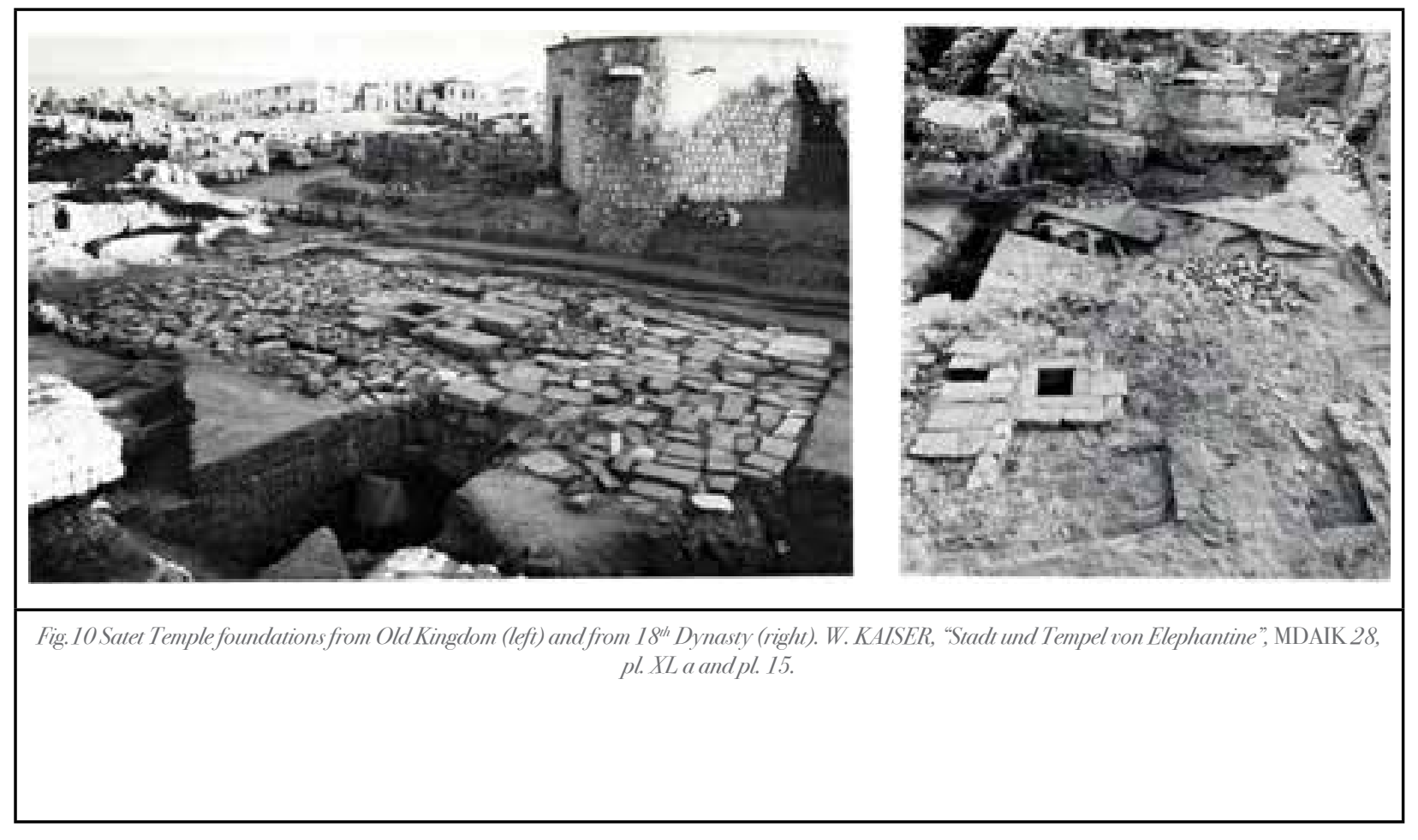

12

\section{B. Signage}

The actual problem of the current signage is divided into two parts:

a. The ink used to print the text is of the same kind used in printed newspapers, which is very sensitive to sunlight.

b. The glass covering the signs in contrary doesn't protect but it lets UV rays pass through it, which negatively affects the ink and make it disappear.

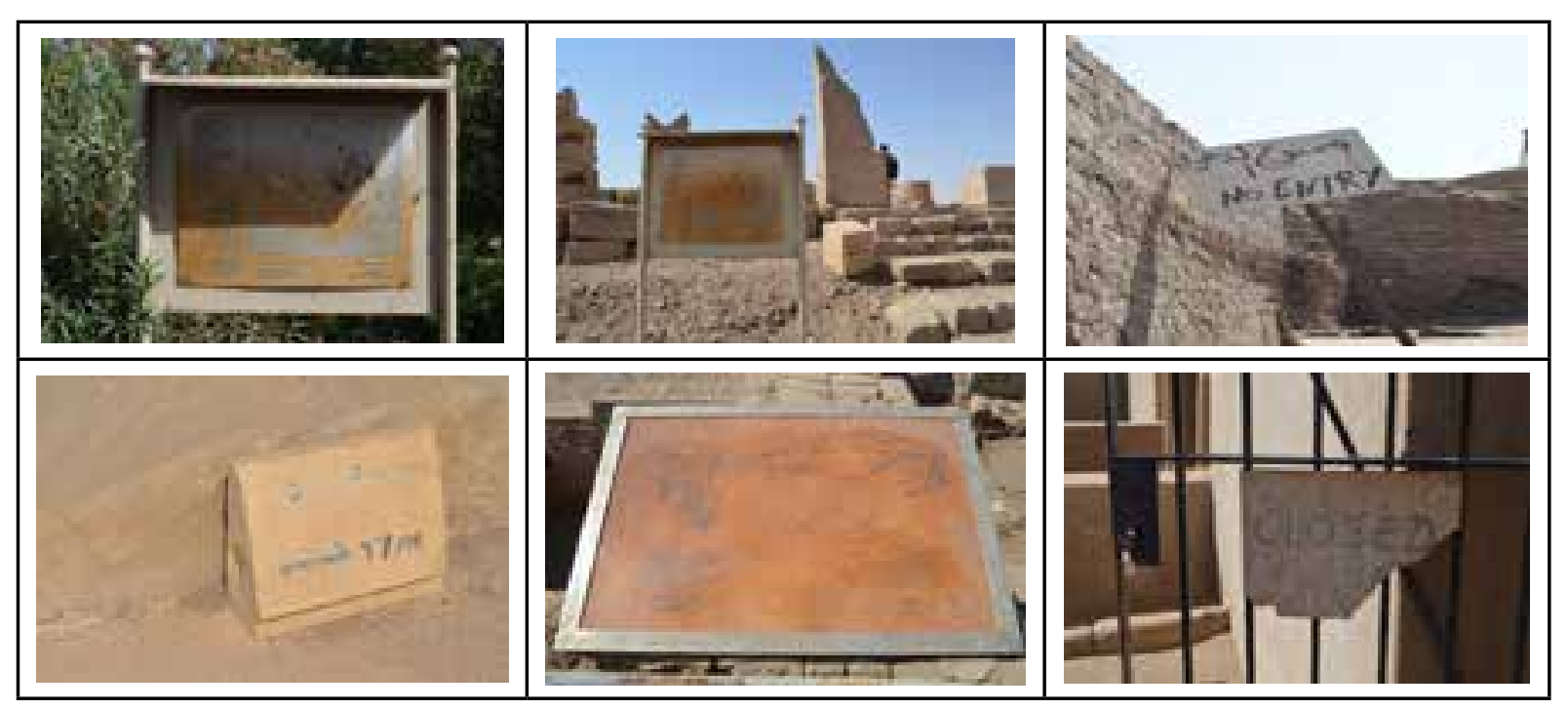

Fig. 11 Examples of bad signage. (ONesma Ahmed, 2015.

After interviewing two Egyptian specialists ${ }^{32}$ in this domain and searching on the internet, two solutions that might be practical for the site were found out.

\section{(1) Silk-Screen Process}

This method is the less expensive one. It is a printing method using oily based-paints applied on oil painted finished wood panel to create a flat surface. It uses the same ink used in writing text for publicity on pens, mugs, and even Ramadan lanterns.

For every sign, a silk screen mold should be fabricated $(100 \times 70 \mathrm{~cm})$ with a cost that varies between EGP 200-500. The material of the panel might be MDF, compressed wood (conter in Arabic) or metal. It will be fixed on two iron bars with a horizontal iron frame that will contain the $\operatorname{sign}^{33}$.

32 Tamer Hawas ( 35 years), a painter, a graphic designer and a PHD student at the Faculty of Fine Arts, Helwan Univeristy; Ahmed Masrawy 42 years), MA
in Applied Arts and specialist in Design of Mural paintings. February 252015 


\section{(2) Laser Engraving}

One of the recent techniques that can be used in information panels is the Laser Printing or Laser Engraving. This technique can be used on different materials, e.g., stone, wood or metal ${ }^{34}$. The best way of engraving is on metal, such as aluminum, copper, cobalt or steel, as they are durable materials and available in different types ${ }^{35}$. They are stable materials that can stand outdoors without being damaged by bad weather, sand or wind.

Another issue regarding signage is marking the difference between accessible and protected areas of the site. First of all, visitors should be informed before the visit and on the map they have that not all areas are accessible.

The difference can be marked with colored signs in yellow or red to catch the attention of the visitor. The sign should have a simple text in Arabic and English, explaining that this area is protected and why it is protected. In addition, it should contain a visual aid as a symbol.

Using the same colors, signs should be marked on the ground, too. Furthermore, a simple metal fence can be installed - where possible - to stop any try to step in.

\section{Visitation Routes}

\section{(1) Route Bordure}

\section{a) Colored pebbles ${ }^{36}$}

A clear road from another material is important, so colored pebbles might be a good solution. They could be directly put on the original stone ground which forms the actual path.

Using the natural colored pebbles has many advantages:

1. Vivid colors which will not fade out

2. They are water resistant, so they will create an isolating layer for the route floor

3. They offer a variety of designs in aesthetic forms

4. Numbers and arrows could be easily marked on them. This method is not costly (ca. 1/10 of the granite or basalt pavement price).

\section{b)Environmental}

Another solution would be using natural and environmentally friendly material as a route bordure, e.g., palm tree trunks.

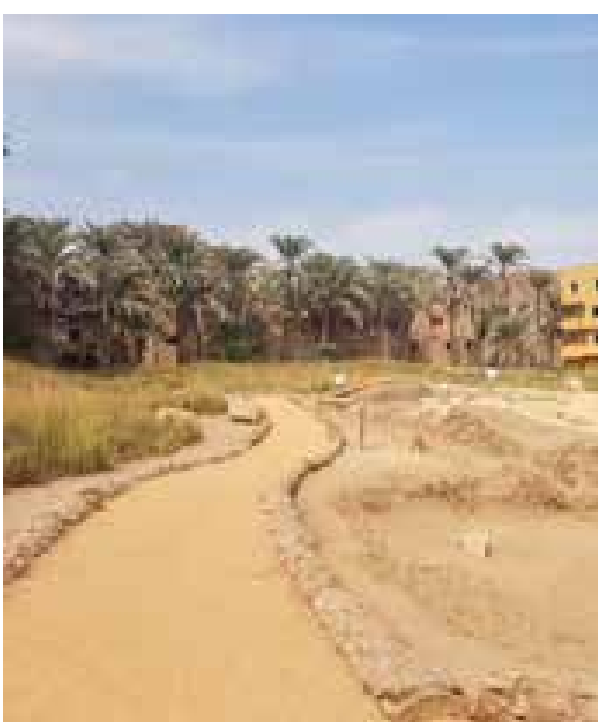

Fig.12 Palm tree trunkiss. OMaissa Moustafa, 2017 


\section{(2) Tours}

With a better marketing policy for the island, the site could be included in the tourist map as a half day visit, advised in the afternoon to avoid the harsh sun and to enjoy more the golden sunlight of this time of the day and its refl on the monuments.

The suggestion is to offer two tours with different monuments according to the time of visitors (same fees or providing a second gate before the reconstruction area). It is worth mentioning that the Nilometers have been the main requested attraction to visit, according to the interviews held by the researchers with many visitors on the site from different nationalities. Thus, the suggested tours are as following:

\section{a) The Long Tour (1 $1 \frac{1}{2}-2$ hours)}

1. Nilometer of Satet Temple (10)

2. Settlements and fortifications of the Old Kingdom (4)

3. Blocks of Khnum Temple (with potential translation) (5)

4. The Gate of Nectanebo of Khnum temple (13)

5. Colored granite blocks of Khnum temple from the New Kingdom

6. General view of the southern part (sector made by sebbakhin with an explanatory sign of what they did in the past) and the Gate of Amenhotep III (14)

7. Granite Naos of Nectanebo with an explanatory sign

8. Panoramic view of the city (17)

9. Heqaib Sanctuary (view from above or inside with an extra ticket for specialized visitors with carrying capacity of max. 10 people) $(18)$

10. Middle Kingdom Settlement (19)

11. The reconstruction area of Satet Temples

(Finishing the archeological part with the visit of the reconstructed temples of 6th dynasty and 18th dynasty would be an awesome end for the visit. However, tour guides' explanations should be forbidden inside the temples)

\section{b) The Short Tour (1/2 - 1 hour}

1. Nilometer of Satet Temple (10)

2. Settlements and fortifications of the Old Kingdom (4)

3. Blocks of Khnum Temple (with potential translation) (5)

4. Nilometer of Khnum Temple (7)

5. The Gate of Nectanebo of Khnum Temple (13)

6. Colored granite blocks of Khnum temple from the New Kingdom
7. Granite Naos of Nectanebo with an explanatory sign

8. Panoramic view of the city (17)

In the case of opening the two museums to visitation, another 30 to 45 minutes will be added to the tour.
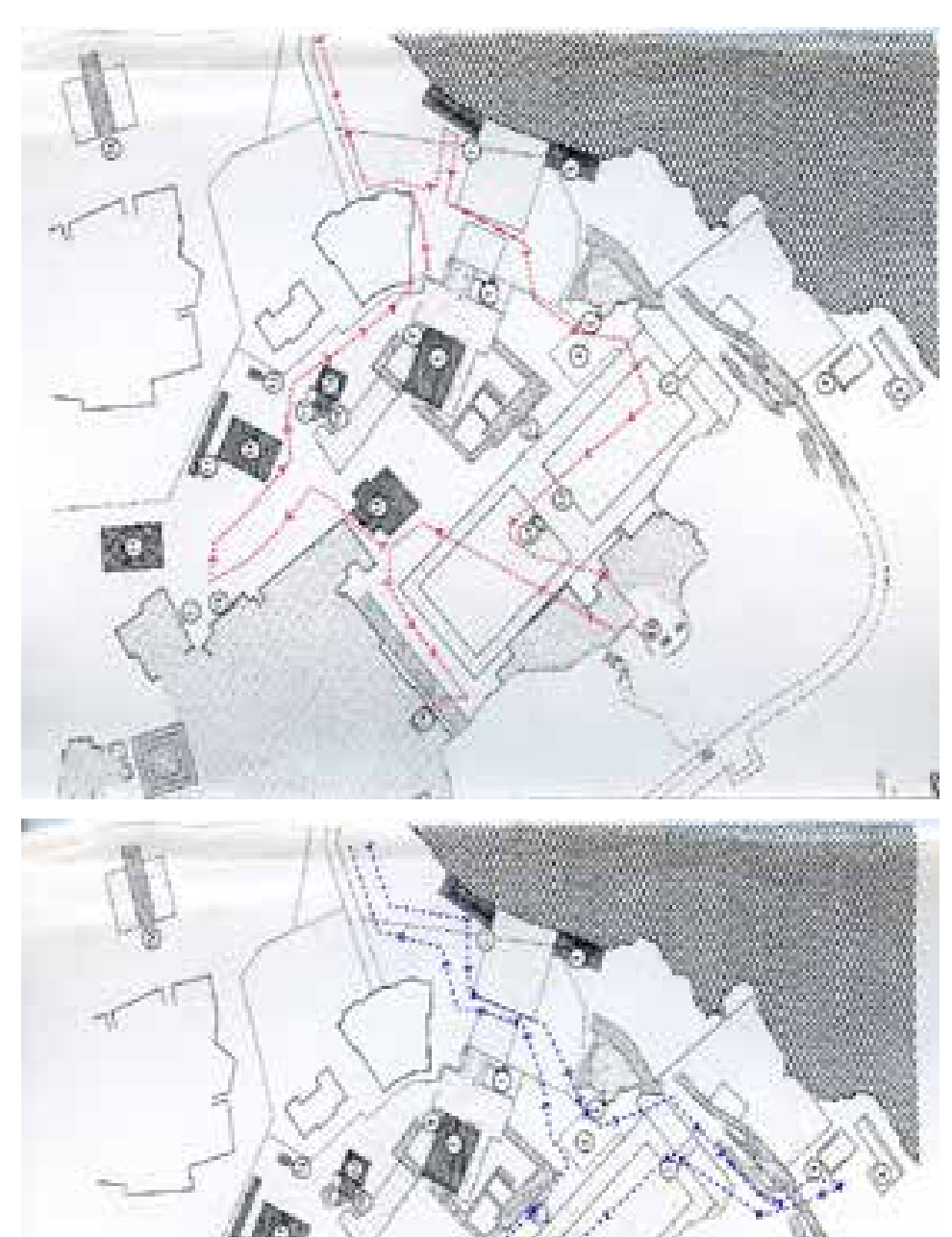

20.

[6.8

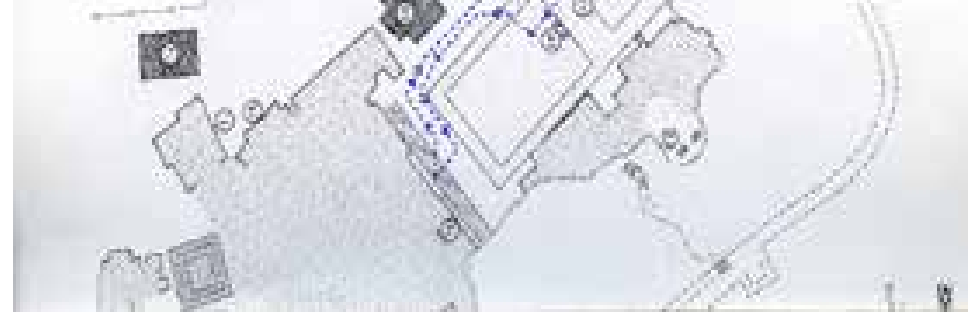

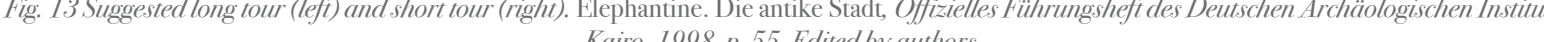




\section{Community Involvement}

Credibility, Conservation, Capacity-Building and Communication, or the four Cs, have been adopted as main strategic objectives of the World Heritage Convention Declaration which was held in Budapest in 2002. They have been completed by a fifth $\mathrm{C}$, for Community, by the World Heritage Committee in 2007 at its 31 st session in Christhurh, New Zealand ${ }^{37}$. Since this time, Local community is considered as a strong stakeholder in any heritage site. They have a great role and
importance to protect and develop the sites. Their roles usually depending on what benefits they get from the site and their involvement of the site. People living in the area of any heritage sites are part of the site itself and its heritage. For this reason, managing and planning the local community and increasing their economic level by involving them in For this reason, managing and planning the local community and increasing their economic level by involving them in
the activities are effective ways to manage and protect the whole site ${ }^{38}$. Training programs conducted by professional the activities are effective ways to manage and protect the whole site ${ }^{38}$. Training programs conducted by professional
people for the local community is very important to make them able to work in the tourism sector as a source of their income $^{39}$

In order to make a good connection with the local community in elephantine island many steps should be done:

1. Other stakeholders have to involve the local community in the decision making 40 $^{0}$. In Elephantine Island, the as one of the main stakeholders.

2. Local community should be involved in the tourism and conservation activities ${ }^{41}$. So, the site could provide local guides, from the island's community to make the tours on the island. Moreover, the DAI and the Ministry of antiquities have to hire people from the island in the conservation process after offering them many training courses.

3. Stakeholders need to establish ways of communication between them to develop the site. That could be realized by a well-educated and well-connected site manager.

4. Providing services have to be offered for the local communities, such as: the infrastructure in the island, enlightening the island and a recycling garbage project (pl. III). These are some services that other stakeholders can cooperate with each other to offer

Moreover, increase the awareness of people by giving those lectures, seminars, workshops which give them general information about the importance and values of the site ${ }^{42}$. Another important issue is to increase the role of both wominformation about the importance and values of the site $^{42}$. Another important issue is to increase the
en and young people by involving them and offering some jobs that they can get benefits from ${ }^{3}$.

A previous successful example was done in Dahshur Archaeological site by the UNDP/Spain MDG Achievement fund, under the name of "The Dahshur World Heritage Site Mobilization of Cultural Heritage for Community Development", might be taken as a model for training the local community. Unfortunately, the program's output was not continued because of the political problems of the country ${ }^{44}$. The training program should aware the local community and train them to be local tour-guides inside the lasland, know their heritage and the importance of the Archaeological site.

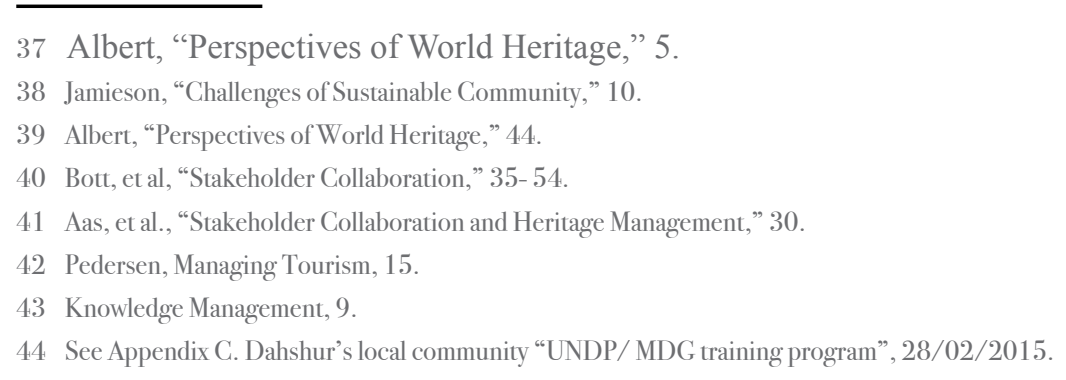

Finally, one of the successful ways is to link the children with their own heritage and culture and raise their awareness with the values and the importance of the heritage place. They have to learn this in courses at their schools ${ }^{45}$, as these children will protect the site when they grow up after knowing its importance. Visits to the site are totally important, with well-educated tour guides or well trained teachers to make them linked to the archaeological places and get information about them.

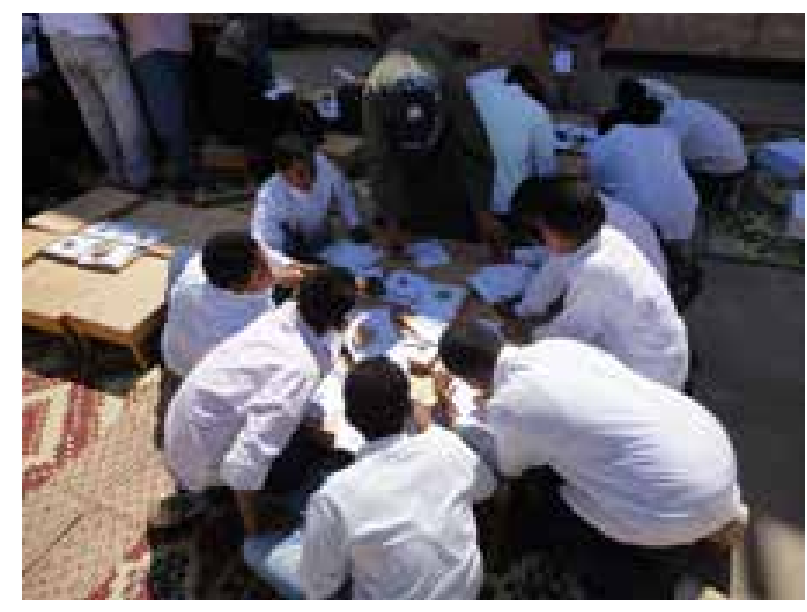

Fit. 14 A worlshhop for. school.sudents on Elephantine Island organized br DALI. ONesma Ahmed, 201.5.

\section{Marketing Campaign}

The campaign will be divided into different phases according to the timeline planned. Each phase includes a number of activities that should lead to building awareness as well as attracting visitors to this desired destination. ${ }^{46}$

\section{A. Phase One:}

The campaign will start with the "Introduce Phase"; this phase works on the awareness building targeting the consumer to know about Elephantine Island, its history, available monuments and any events organized. Therefore, a websit for Elephantine Island will be designed to attract the visitors and can be used as awareness platform for the island in the campaign and hyperlinked in other famous websites for traveling such as Trip Advisor and Travel Egypt. Due to the lack of finance, activities are of low-cost such as digital ads and social media spread. Also launching awareness events is crucial to drive first time visitors to Elephantine through the technology that will be used such as GIS and Virtual Constrictions.

\section{B. Phase Two:}

It will be focusing on reinforcing the island as "the go-to" place. In this phase we will focus on the message that visitor will receive, which is "Elephantine" is a must-see destination in Aswan. The success point of this phase is making tourists and local residents start heading to Elephantine as a historical site, hence attracting more visitors of different background and interests to know more 
about Egypt's historic island. Due to the low budget, we can create effective and memorable campaign. Leveraging different media such as: Online media, including interactive ads and banners on websites, print media, social media, publicity, search engines and events held in the site.

\section{Phase Three:}

Third and final phase is "Sustain," this phase focuses on stabilizing and maintaining the rate of expected visitors to the site. This is done through several activities such as including the site in different itineraries and partnership deals with entities such as Ministry of Tourism, Tourism Authority and Chamber of Tour Operators. Moreover, according to the competitors' analyses tables included in this paper of the Botanical Garden managed by Aswan Governorate, we recommend creating a partnership with the governorate. Elephantine Island can be bundled with other sites and we can start a new campaign called "Visit Aswan Islands" promoting the islands in Aswan.

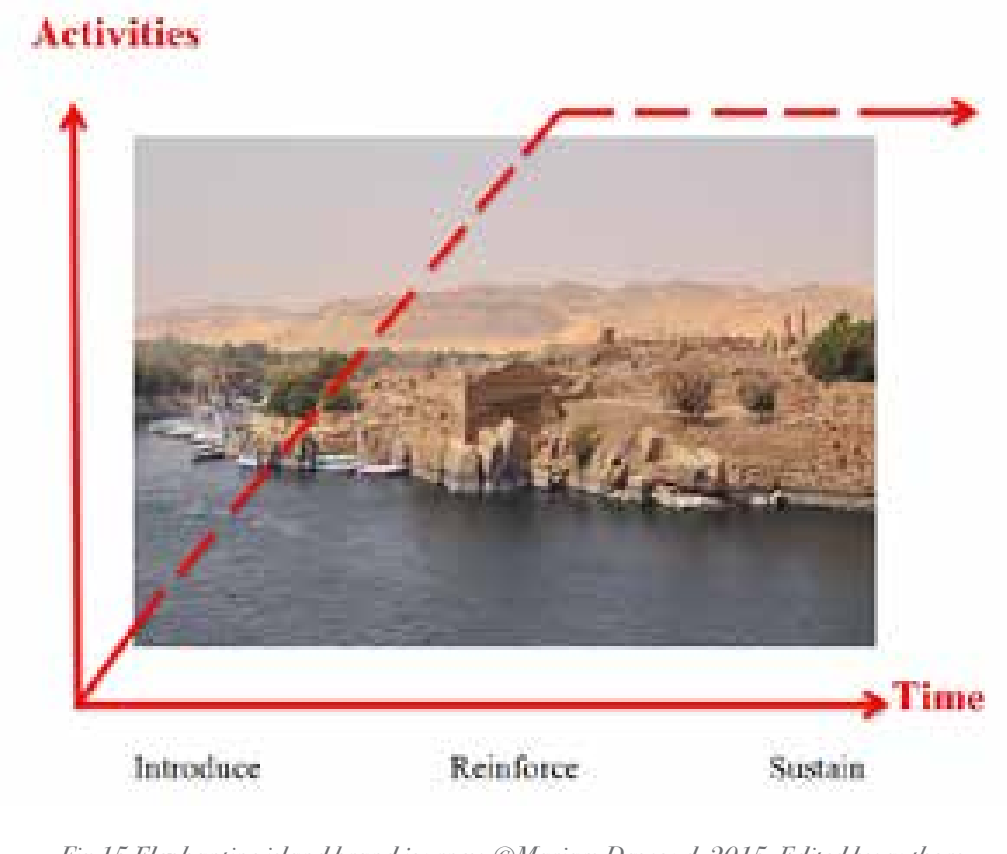

Our target market segments are foreign tourists, domestic tourists, local residents, students and professionals as well. The foreign visitors who usually visit Aswan, for more than two days and stay in hotels, not in Nile cruise are considered an important target as well because they will be always interested to see more in Aswan, besides the traditional attractions such as Philae Temple, the High Dam and the Unfinished Obelisk. The students and professionals are also important target audiences since the scientific value of the site is extremely significant and one of our main goals is to let the new generations know about their history.

\section{Tone of Voice:}

The campaign's tone of voice will have to be both modern and up to date to appeal to the target market yet keep the image of the heritage and old treasures it holds.

\section{Conclusion}

Interpretation at heritage sites is about informing, educating or extending people's understanding of the site. It can be delivered in many ways ${ }^{47}$. The Society for Interpreting Britain's Heritage defined interpretation as the following:

"Interpretation is the process of explaining to people the significance of the place or object they have come to see, so that they enjoy their visit more, understand their heritage and environment better, and develop a more caring attitude towards conservation." ${ }^{\text {" }}$

A successful visitor management plan for a heritage site - as Elephantine Island - is the process of achieving the conservation of the site on one hand and the visitor satisfaction on the other ${ }^{49}$. A good interpretation of the site is important to increase the visitor's experience, but it is not enough.

In order to realize the main goal of the visitor management plan and to create successful sustainable tourism, many issues have to be considered, such as investing in place (permanent maintenance) and people (local community and staff in heritage sites), respecting their local rights and obligations, recognizing the significance of the heritage site and keeping on to preserve and protect it, looking after visitors' safety and last but not least responsible marketing and promoting ${ }^{50}$. 


\section{Bibliography:}

- Aas, Christina, Adele Ladkin, and John Fletcher. “Stakeholder Collaboration and Heritage Management.” Annals of Tourism Research 32,no. 1(2005):28-48, doi:10.1016/j.annals.2004.04.005.

- Agnew, Neville, ed. Conservation of Ancient Sites on the Silk Road: Proceedings of the Second International Conference on the Conservation of Grotto Sites, Mogao Grottoes, Dunhuang, People’s Republic of China, June 28-July 3, 2004. Getty Publications, 2010

- Albert, Marie-Theres. "Perspectives of World Heritage: Towards Future-oriented Strategies with the Five 'Cs'." In Community Development through World Heritage, edited by Albert, Marie-Theres, Marielle Richon, Marie José Viñals, Andrea Witcomb, 32-38. Paris: UNESCO World Heritage Centre, 2012.

- Amin, Mutwakil A. "Ancient Trade and Trade Routes between Egypt and the Sudan, 4000 to 700 BC." Sudan Notes and Records 51 (1970): 23-30.

- Bott, Amy Louise, Simone Grabowski, and Stephen Wearing. "Stakeholder Collaboration in a Prospective World Heritage Area: the Case of Kokoda and the Owen Stanley Ranges," Cosmopolitan Civil Societies: An Interdisciplinary Journal 3, no. 2 (2011): 35 .

- Haukeland, Jan Vidar, Odd Inge Vistad, Karoline Daugstad, and Heidi G. Degnes-Ødemark. "Educational Tourism and Interpretation.” Oslo: Norwegen Centre for Transport Research, 2013. http://www.nmbu.no/sites/default/files/ wysiwyg_inserts/protour_arbeidsdokument_mo_50369-2013.pdf

- Introducing Young People to the Protection of Heritage Sites and Historic Cities. A Practical Guide for School Teachers in the Arab Region, 2nd ed. Paris: UNESCO - ICCROM, 2006.

- Jamieson, W., "The Challenges of Sustainable Community Cultural Heritage Tourism”, paper presented by the UNESCO Workshop on Culture, Heritage Management and Tourism, Bhaktapur, Nepal, April, 2000,.

- Knowledge Management for Culture and Development. MDG-F Joint Programmes in Egypt, Mauritania, Morocco and the Occupied Palestinian Territory. UNESCO, 2012.

- Pedersen, A. Managing Tourism at World Heritage Sites: a Practical Manual for World Heritage Site Managers, a report issued by UNESCO World Heritage Centre. (2002).

- Elephantine. Die Antike Stadt, the official booklet of the German Archaeological Institute. Cairo: German Archaeological Institute Cairo, 1998.

- “Global Code of Ethics for Tourism”. UNWTO. Accessed March 23, 2015. http://ethics.unwto.org/en/content/globalcode-ethics-tourism-article-5.

• Habachi, Labib. “Elephantine.” Lexikon der Ägyptologie 1 (1975): 1217-1225

- Habachi, Labib. “Hekaib the Deified Governor of Elephantine.” Archaeology 9, no. 1 (1956): 8-15.

• Habachi, Labib. “Elephantine IV. The Sanctuary of Heqaib.” Archäologische Veröffentlichungen 33 (1985)

- Ikram, Salima, Christian Knoblauch. “Elephantine and Aswan.” In Ancient Nubia. African Kingdoms on the Nile, edited by Fisher, Marjorie M., Peter Lacovara, Salima Ikram, and Sue D’Auria, 406-410. Cairo: American University in Cairo Press, 2012
- "Laser Marking and Laser Engraving Metal". Trotec. Accessed March 8, 2015. http://www.troteclaser.com/en-US/ Materials/Pages/Metal.aspx.

- "Marketing Introduction”. USC. Accessed March 11, 2015. http://www.consumerpsychologist.com/marketing introduction.html.

- Ministry of Antiquities. “Antiquities of Aswan and Nubia.” Records of Visitors Numbers, 2015.

- Moscardo, Gianna. "Interpretation and Sustainable Tourism: Functions, Examples and Principles." Journal of Tourism Studies 9, no. 1 (1998): 2.

- Raue, Dietrich. "Sanctuary of Heqaib." In UCLA Encyclopedia of Egyptology, edited by Willeke Wendrich. Los Angele (2014): 1-15. http://digital2.library.ucla.edu/viewFile.do?contentFileId=2320439

- “Stone Laser Engraving”. Trotec. Accessed March 3, 2015. http://www.troteclaser.com/en-US/Materials/Pages/Stone

- Ziermann, Martin. "Elephantine XVI. Befestigungsanlagen und Stadtentwicklung in der Frühzeit und im frühen Alten Reich.” Archöologische Veröffentlichungen 87. Cairo: Verlag Philipp von Zabern, 1993. 